\title{
NEW SPECIES OF DIAPHERA ALBERS, 1850 (GASTROPODA: PULMONATA: STREPTAXIDAE) FROM KALIMANTAN, BORNEO (INDONESIA)
}

\author{
JAAP J. VERMEULEN
}

JK Art and Science, Lauwerbes 8, 2318 AT Leiden, Netherlands (e-mail: jk.artandscience@gmail.com); (D) https://orcid.org/0000-0002-8505-0319

ABSTRACT: Eight new species and one new subspecies of the genus Diaphera (Streptaxidae) are described: $D$. amphoreomorpha, D. crenata, D. kionion, D. striata, D. auriculata, D. crassa, D. rhysauchen rhysauchen, D. rhysauchen percostata, and $D$. sororcula. All species originate from Kalimantan, the Indonesian part of the island of Borneo.

KEY WORDS: land snails; Diaphera; Kalimantan; Borneo

Publication LSID 6797AC71-002D-445D-AA8F-61A55D4D59A5

\section{INTRODUCTION}

Compared to the numbers of species recorded from continental S.E. Asia, only few streptaxid (sensu lato, i.e. including Diapheridae) snails are known from the island of Borneo: only 12 species have been recorded so far, excluding the introduced Gulella bicolor (T. Hutton, 1834) (VERMEULEN 1990, 1991, 2007).

The four streptaxid genera found on Borneo occur in mutually exclusive areas of endemism, see Fig. 1. Three are found in Sarawak: Platycochlium Laidlaw, 1950 (3 species) in limestone ranges S. of Kuching; Bruggennea Dance, 1972 (3 species), on Bukit Sarang, a minute limestone hill in the Tatau river valley; the only known Borneo species of Sinoennea Kobelt, 1904, in the Gunung Mulu area. The fourth genus, Diaphera Albers, 1850, is known from N.E. Sabah and the extreme S.E. of Kalimantan, with a wide gap in between.

The nine taxa of Diaphera described in this paper suggest a less discontinuous occurrence of the genus along Borneo's east coast. The distribution pattern with mutually exclusive areas of endemism is repeated below generic level. The species groups (Groups 1 to 3 in the key, below) which can be distinguished morphologically are restricted to mutually exclusive areas, see Fig. 1: Group 1 occurs in the Meratus mountains and karst areas to their east, Group 2 on Sangkulirang peninsula, and Group 3 in E. Sabah. More representative collecting in Kalimantan is needed to see if these areas of endemism hold true and do not blend into each other with increasing collecting density.

It is difficult to point out potential affinities based on resemblance between the Borneo Diaphera and extralimital species. DANCE (1970, subsp. D. wilfordi) notes a similarity between the Borneo species and the Philippine 'group typified by D. morleti (Hidalgo, 1889)'. With the pictorial overview of the Philippine Diaphera in ZILCH (1961) this can be narrowed down to a similarity between the species of Group 1, below, and two Philippine species most resembling these, namely D. morleti and D. dilophia (Quadras et Möllendorff, 1895); all species without the bulge on the last part of the last whorl that characterises Groups 2 and 3 of the Borneo species. The two Philippine species differ in the more prominent basal ridge.

Several papers on continental Asian Diaphera together provide an overview (SUTCHARIT et al. 2010, Chen \& PÁll-Gergely 2020, PÁll-Gergely et al. 2020). No species particularly resembles the Borneo ones, although the bulge on the last part of the last whorl occurs in D. prima Panha in SUTCHARIT et al. (2010), and D. turbanophora Páll-Gergely et Grego 


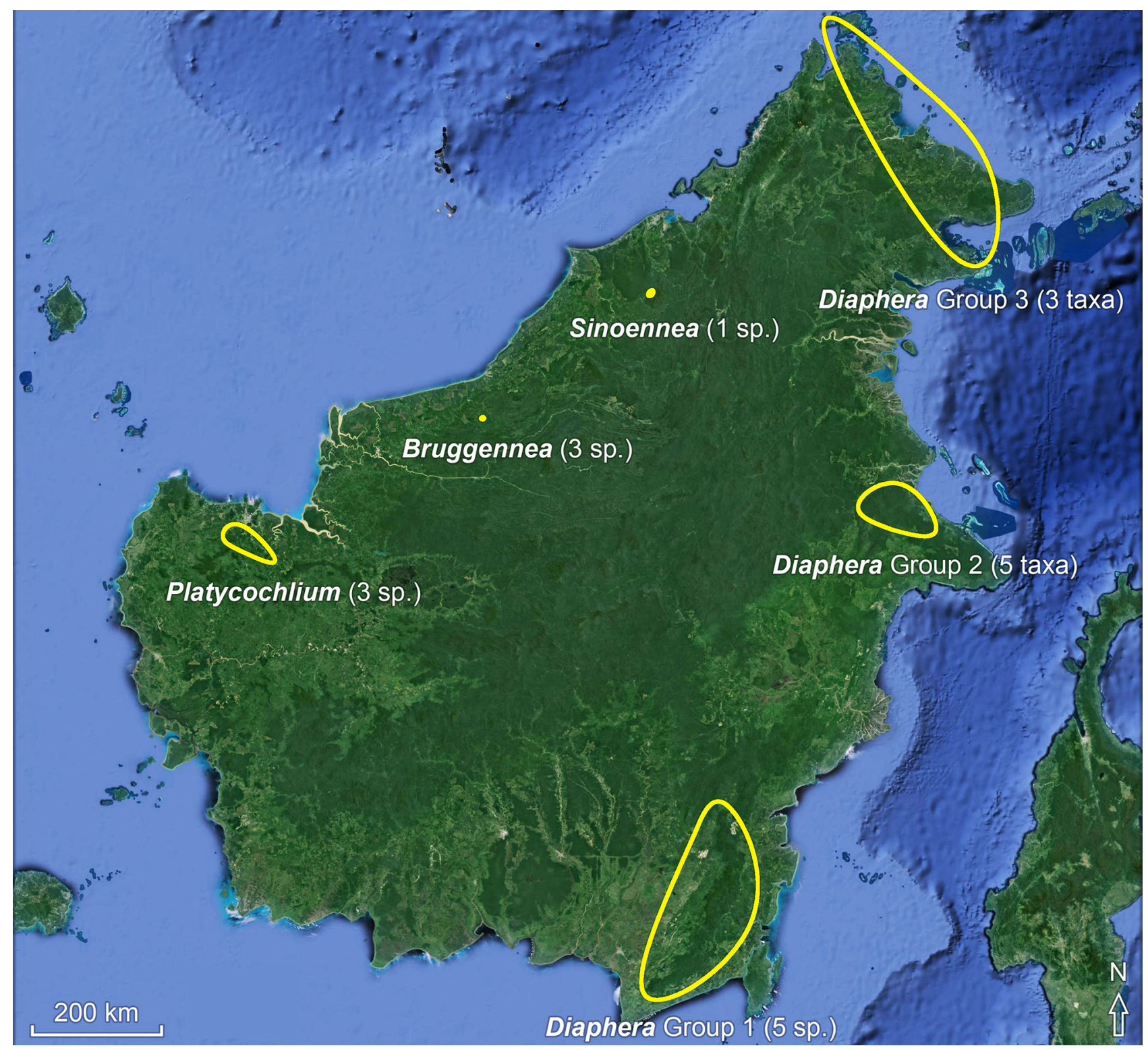

Fig. 1. Distribution of supraspecific entities of Streptaxidae in Borneo

in PÁlL-Gergely et al. (2020). Both differ from the Borneo species in their distinctly elongated shells; the second also has the last whorl connected to the spire, and a closed umbilicus.

In its present delimitation the genus includes species so divergent in shell shape that one wonders whether the diagnostic (though polythetic) character of Diaphera (a partly or entirely detached last whorl) reflects true phylogeny, or whether the genus is a mere convenience, as also suggested by PÁLLGERGELY et al. (2020).

\section{MATERIAL AND METHODS}

The terminology of apertural barriers follows VERMEULEN (1990, 1991, 2007) but deviates from SuTCHARIT et al. (2010), CHEN \& PÁll-GERGELY (2020) and PÁlL-Gergely et al. (2020). The angularis in the present paper is the same as the "parietalis' in the sources listed, and the palatobasalis is the same as the 'lower palatalis'. The spire is defined as the shell minus the last, partially detached whorl.
The material derives from the private collection of the author (' $\mathrm{V}$ ' in the lists of examined material). Type specimens are stored in the Hungarian Natural History Museum, Budapest ('HNHM'). The illustrations were drawn by the author, with the aid of a Wild M8 stereo microscope with a Camera Lucida device. The author claims copyright of all illustrations. 


\section{SYSTEMATIC PART}

\section{Family Streptaxidae J. E. Gray, 1860}

\section{Genus Diaphera Albers, 1850}

Key to informal groups of Borneo species of Diaphera

1. Aperture with a columellar lamella starting close to the peristome. Last part of the last whorl without a bulge on the columellar side

Group 1

1a. Aperture with a columellar lamella deep inside. Last part of the last whorl with a distinct bulge on the columellar side

2. Aperture with a palatal tooth or lamella with its crest almost meeting the crest of the angular lamella

Group 2

2a. Aperture with a palatal tooth or lamella with its crest well distant from the crest of the angular lamella, or aperture without a palatal tooth or lamella

Group 3

\section{GROUP 1}

This group includes the species described below, as well as D. porrecta (E. von Martens, 1884).

\section{Diaphera amphoreomorpha sp. nov.}

Figs 2-3

\section{LSID 35EFA009-E4BE-4659-A827-C98B114730EB}

Examined material. Indonesia: Kalimantan Timur. Meratus Mts., N. part: Bukit Butuk near Muara Komang (V3526/>10 shells); Gunung Melihat, foot of S.-facing slope between road and river (holotype: HNHM 104874, paratypes: V2960/>10).

Diagnosis. It differs from $D$. kionion and $D$. porrecta (E. von Martens, 1884) in the ellipsoid spire (versus (ellipsoid-)cylindrical or (ovoid-)cylindrical) which is distinctly wider (width of spire minus last whorl 3.0-3.5 $\mathrm{mm}$, versus $2.0-2.5 \mathrm{~mm}$ ). Locally somewhat ribbed shells may resemble $D$. striata but differ in the ellipsoid (versus an (ellipsoid-)obovoid to (cylindrical)obovoid spire), and generally wider spire (spire $\mathrm{h} / \mathrm{w}$ index 1.5-1.9, versus 1.1-1.5).

Description. Shell small, thin, opaque to slightly translucent, white. Surface shiny. Spire ellipsoid, with 2-3 varices, apex not or hardly oblique. Whorls: first whorls moderately convex, grading to a slightly to moderately convex last whorl, suture impressed; last whorl with an obtuse basal keel, well-demarcated on both sides; umbilical side without bulge near the aperture, surface with two spiral ridges which are approx. equally prominent, somewhat flattened towards the aperture, elsewhere obtusely angular with a deep furrow in-between; last $1 / 4$ whorl detached but staying rather close to the spire. Sculpture. Protoconch approx. smooth. Teleoconch. Radial sculpture: distinct, rather densely arranged crenulations below the suture which locally continue as inconspicuous, rather closely spaced, thin, rounded riblets, only slightly curved except on the first part of the last whorl where they are somewhat more distinctly curved; close to the base of the last whorl similar but more elongated crenulations; umbilicus with distinct, rather densely arranged, flat radial ribs, somewhat fewer in number than on the outer surface of the last whorl. Spiral sculpture absent, or with traces of faint, well-spaced threads on the last two whorls. Aperture obliquely elliptic to obtusely rhombiform. Peristome thickened and spreading, somewhat less so on the parietal side, receding on the upper palatal side. Four apertural teeth: one prominent angular lamella starting on the edge of the peristome, approx. without a notch in its crest where it is closest to the palatalis and reaching deep inside; one conical palatal knob slightly behind the inner edge of the peristome, its apex somewhat distant from the crest of the angularis; one palatobasal knob rather deep inside the aperture; one columellar lamella starting slightly behind the inner edge of the peristome.

Dimensions: shell height $6.0-7.3 \mathrm{~mm}$; shell width 3.1-3.7 mm; spire height 3.5-5.0 mm; spire width $3.0-3.5 \mathrm{~mm}$; spire $\mathrm{h} / \mathrm{w}$ index $1.1-1.5$; number of whorls 5 1/4-6 3/4; umbilicus $0.65-0.85 \mathrm{~mm}$ wide, or $19-26 \%$ of spire width; aperture height 1.6 $2.1 \mathrm{~mm}$; aperture width $1.7-2.0 \mathrm{~mm}$.

Ecology. Disturbed lowland rainforest on limestone bedrock. Altitude 0-100 m a.s.1.

Distribution. Indonesia, Kalimantan Timur, N. part of the Meratus mountains.

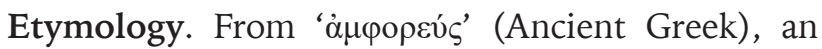
amphora, a jar with a narrow neck, and ' $\mu о \rho \varphi$ ', shape, referring to the shell outline.

\section{Diaphera crenata sp. nov.}

Figs 4-5

\section{LSID D14D0A7D-442E-4513-BE26-7D4A082A3C64}

Examined material. Indonesia: Kalimantan Selatan. Meratus Mts., N.W. part: Gunung Siamang, desah Liu, c. $30 \mathrm{~km}$ E. Tandjung (V3112/>10 shells). Meratus Mts., W. flank: Nateh near Batu Tangga, c. 18 km E. of Barabai (V18377/>10, holotype: HNHM 104877, paratypes: V3038/>10).

Diagnosis. In group 1 characterised by the palatobasal tooth in the aperture: absent or present, if present, very deep inside the aperture (hardly visible in frontal view) and often inconspicuous, a slight gibbosity on the palatal edge of the basal furrow (versus always present, rather deep inside the aperture but 
clearly visible in frontal view). Generally, it is similar to $D$. amphoreomorpha and D. kionion and intermediate between these in shape and size of the spire; it differs from the first in the narrower spire (width 2.2$2.9 \mathrm{~mm}$; spire $\mathrm{h} / \mathrm{w}$ index $1.6-2.1$, versus $3.0-3.5 \mathrm{~mm}$; $\mathrm{h} / \mathrm{w}$ index 1.1-1.5), it differs from the second in the more distinctly ellipsoid(-obovoid) spire (versus a more distinctly cylindrical spire).

Description. Shell small, thin, opaque to slightly translucent, white. Surface shiny. Spire ellipsoid (-obovoid), sometimes ellipsoid-cylindrical, with 2-3 varices, apex not or hardly oblique. Whorls: first whorls moderately convex, grading to a slightly to moderately convex last whorl, suture impressed; last whorl with an obtuse basal keel, well-demarcated on both sides; umbilical side without bulge near the aperture, surface with two spiral ridges which are approx. equally prominent, somewhat flattened towards the aperture, elsewhere obtusely angular with a deep furrow in-between; last 1/4 whorl detached, rather close to the spire to distant from the spire. Sculpture. Protoconch approx. smooth. Teleoconch. Radial sculpture: distinct, rather densely arranged to well-spaced crenulations below the suture which only locally continue as a few inconspicuous, wellspaced, thin, only slightly curved, rounded ribs; close to the base of the last whorl with similar, usually less distinct and more elongated crenulations; umbilical opening with distinct, closely spaced radial ribs, somewhat fewer in number than on the outer surface of the last whorl. Spiral sculpture absent. Aperture obliquely elliptic, obliquely ovate to obtusely rhombiform. Peristome thickened and spreading, somewhat less so on the parietal side, receding on the upper palatal side. Two to four apertural teeth: one prominent angular lamella starting on the edge of the peristome, approx. without a notch in its crest where it is closest to the palatalis, and reaching deep inside; with or without one palatal knob, when present located slightly behind the inner edge of the peristome, its crest close to or somewhat distant from the crest of the angularis; with or without one palatobasal knob, when present located deep inside the aperture (hardly visible in frontal view), often inconspicuous, a slight callosity on the palatal edge of the basal furrow; one columellar lamella starting slightly behind the inner edge of the peristome.

Dimensions: shell height $5.4-7.3 \mathrm{~mm}$; shell width 2.2-3.3 mm; spire height $3.8-4.9 \mathrm{~mm}$; spire width 2.2-2.9 mm; spire $\mathrm{h} / \mathrm{w}$ index 1.6-2.1; number of whorls 5-7 1/8; umbilicus $0.25-0.75 \mathrm{~mm}$ wide, or $10-28 \%$ of spire width; aperture height $1.4-1.8 \mathrm{~mm}$; aperture width $1.3-1.8 \mathrm{~mm}$.

Ecology. Disturbed lowland rainforest on limestone bedrock. Altitude 200-300 m a.s.l.

Distribution. Indonesia, Kalimantan Selatan, W.facing flank of the Meratus mountains.
Etymology. From 'crena' (Latin), 'notch', referring to the suture of the spire.

Note. The material shows variation in shell size, spire shape and the presence/absence of a palatobasal knob in the aperture. Two rather different-looking shells from the type locality are illustrated. However, it appears impossible to distinguish discrete forms that could be regarded as subspecies.

\section{Diaphera kionion sp. nov.}

Figs 6-7

\section{LSID 761B9DEC-0283-4C1B-97DB-3298287B695C}

Examined material. Indonesia: Kalimantan Selatan. Meratus Mts., W. flank: Bukit Pagat $8 \mathrm{~km} \mathrm{S.E.} \mathrm{of}$ Barabai (holotype: HNHM 104878, paratypes V3794/>10 shells).

Diagnosis. Within Group 1, D. kionion shares the slender, approx. cylindrical spire with $D$. porrecta (E. von Martens, 1884). It differs from $D$. porrecta in the hardly oblique or straight apex (versus distinctly oblique) and in the (ellipsoid-)cylindrical spire (versus ovoid-cylindrical). Besides, the shells of $D$. kionion are often higher (shell height (5.1-)6.2-8.0 mm, versus 5.1-6.6 mm).

Description. Shell small, thin, opaque to slightly translucent, white. Surface shiny. Spire (ellipsoid) cylindrical, rarely ellipsoid (a poorly developed specimen), with 2-3 varices, apex straight or hardly oblique. Whorls: first whorls moderately convex, grading to a slightly convex last whorl, suture impressed; last whorl with an obtuse basal keel, well-demarcated on both sides; umbilical side without bulge near the aperture, surface with two spiral ridges which are approx. equally prominent, flattened towards the aperture, elsewhere obtusely angular with a deep furrow in between; last 1/4 whorl detached and rather distant from the spire. Sculpture. Protoconch approx. smooth. Teleoconch. Radial sculpture: distinct, rather closely arranged to well-spaced crenulations below the suture which only locally continue as a few inconspicuous, well-spaced, thin, only slightly curved, rounded ribs; close to the base of the last whorl with similar but more elongated crenulations; umbilicus with distinct, moderately to widely spaced, flat radial ribs, approx. as many as on the outer surface of the last whorl. Spiral sculpture absent. Aperture obliquely ovate to obtusely rhombiform. Peristome thickened and spreading, somewhat less on the parietal side, receding on the upper palatal side. Four apertural teeth: one prominent angular lamella starting on the edge of the peristome, with a slight notch in its crest where it is closest to the palatalis and reaching deep inside; one conical palatal knob on the inner edge of the peristome, its apex moderately distant from the crest of the angularis; one palatobasal knob rather deep inside the aperture; one columellar 

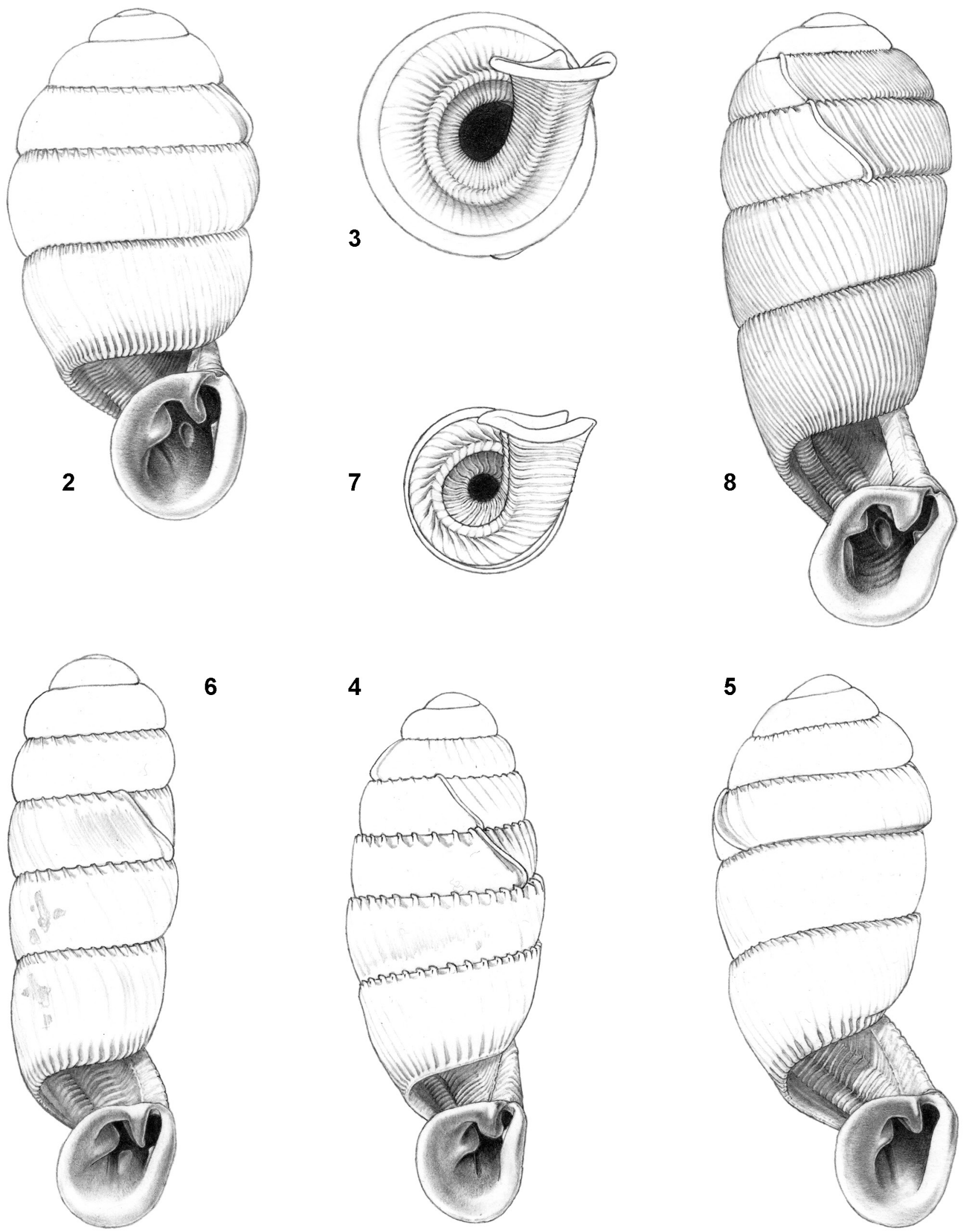

Figs 2-8. Diaphera Group 1: 2 - Diaphera amphoreomorpha sp. nov., holotype, frontal view, shell height $6.5 \mathrm{~mm}, 3$ - same shell, umbilical view; 4 - Diaphera crenata sp. nov., holotype, frontal view, shell height $6.8 \mathrm{~mm}, 5$ - paratype from same locality, frontal view, shell height $7.2 \mathrm{~mm}$; 6 - Diaphera kionion sp. nov., holotype, frontal view, shell height $7.4 \mathrm{~mm}$, 7 - same shell, umbilical view; 8 - Diaphera striata sp. nov., holotype, frontal view, shell height $8.7 \mathrm{~mm}$ 
lamella starting slightly behind the inner edge of the peristome.

Dimensions: shell height (5.1-)6.2-8.0 mm; shell width 2.2-3.0 $\mathrm{mm}$; spire height (3.3-)4.4$5.8 \mathrm{~mm}$; spire width $2.2-2.5 \mathrm{~mm}$; spire $\mathrm{h} / \mathrm{w}$ index (1.4-)1.8-2.6; number of whorls (6 1/4-) $63 / 4-7$ $7 / 8$; umbilicus $0.3-0.6 \mathrm{~mm}$ wide, or $14-25 \%$ of spire width; aperture height $1.5-1.8 \mathrm{~mm}$; aperture width $1.3-1.7 \mathrm{~mm}$.

Ecology. Disturbed lowland rainforest on limestone bedrock. Altitude ca. 100 m a.s.l.

Distribution. Indonesia, Kalimantan Selatan, W.facing flank of the Meratus mountains. So far known from the type locality only.

Etymology. From 'Kíóvıv' (Ancient Greek), 'a small pillar', used as a noun in apposition, alluding to the shell shape.

\section{Diaphera striata sp. nov.}

Fig. 8

LSID FD28771A-83A0-473F-BC90-02E472DD3D54

Examined material. Indonesia: Kalimantan Selatan. Meratus Mts., E. flank: limestone hills along road Benualawas-Limbungan (holotype: HNHM 104882, paratypes: V2863/>10 shells).

Diagnosis. Within group 1 identified by the following set of characters: spire (ellipsoid-)obovoid to (cylindrical-)obovoid, and rather closely arranged, low and narrowly rounded radial riblets present on most of the spire except the apical whorls. It may resemble locally ribbed shells of $D$. amphoreomorpha but differs in the (ellipsoid-)obovoid to (cylindrical-)obovoid spire (versus an ellipsoid spire), and in the generally narrower spire (spire $\mathrm{h} / \mathrm{w}$ index $1.1-1.5$, versus 1.5-1.9).

Description. Shell small, thin, opaque to slightly translucent, white. Surface shiny. Spire (ellipsoid-) obovoid to (cylindrical-)obovoid, with two (exceptionally one) varices, apex straight or hardly oblique. Whorls: first whorls (moderately) convex, grading to an approx. flat to slightly convex last whorl, suture impressed, sometimes deeply impressed in one or two upper whorls; last whorl with an obtuse basal ridge well-demarcated on both sides; umbilical side without bulge near the aperture, surface with two spiral ridges which are flattened and approx. equally prominent towards the aperture, elsewhere along the last whorl with the lower ridge slightly more prominent until receding near the start of the last whorl, both obtusely angular; last $1 / 4$ whorl detached, rather close to rather distant from the spire. Sculpture. Protoconch approx. smooth. Teleoconch. Radial sculpture usually present on most of the spire except the apical whorls: rather inconspicuous but towards the base on the last whorl distinct, rather densely arranged, thin, only slightly curved but on the first part of the last whorl somewhat more distinctly curved, narrowly rounded riblets which start as a fine crenulation below the suture; umbilicus with rather distinct, rather closely spaced, flat radial ribs distinctly fewer in number than on the outer surface of the last whorl. Spiral sculpture absent. Aperture obliquely elliptic to obtusely rhombiform. Peristome thickened and spreading, somewhat less so on the parietal side, receding on the upper palatal side. Four apertural teeth: one prominent angular lamella starting on the edge of the peristome, often with a slightly notched or uneven crest where it is closest to the palatalis, and reaching deep inside; one rather short palatal lamella starting slightly behind the inner edge of the peristome, and with its crest distant from the crest of the angularis (in some shells the two close together deeper in the aperture); one palatobasal knob rather deep inside the aperture; one columellar lamella starting slightly behind the inner edge of the peristome.

Dimensions: shell height 7.1-8.8 mm; shell width 3.2-3.7 mm; spire height 4.1-6.1 mm; spire width 3.2-3.5 mm; spire $\mathrm{h} / \mathrm{w}$ index 1.5-1.9; number of whorls 6-7; umbilicus $0.5-0.8 \mathrm{~mm}$ wide, or $15-23 \%$ of spire width; aperture height and width $2.0-2.2 \mathrm{~mm}$. Ecology. Disturbed lowland rainforest on limestone bedrock. Altitude ca. $100 \mathrm{~m}$ a.s.l.

Distribution. Indonesia, Kalimantan Selatan, karst land along the E. flank of the Meratus mountains. So far known from the type locality only.

Etymology. From 'striatus' (Latin), 'lined', referring to the radial sculpture.

\section{GROUP 2}

The group includes the following species:

\section{Diaphera auriculata sp. nov.}

Figs 9-10

\section{LSID EB185039-05B1-4008-B18E-B56B8995EBA9}

Examined material. Indonesia: Kalimantan Timur. Sangkulirang Peninsula: Gua Meweding near Kampong Tabalar Ulu c. 60 km S.E. of Berau (holotype: HNHM 104875, paratypes: V11856/5 shells).

Diagnosis. It differs from $D$. crassa in its narrower umbilicus $(0.25-0.40 \mathrm{~mm}$, or $8-13 \%$ of spire height, versus $0.8-1.3 \mathrm{~mm}$, or $25-38 \%)$. It differs from $D$. sororcula in its larger size (shell height 7.2-8.1 mm, width $3.0-3.3 \mathrm{~mm}$, versus $4.9-5.9 \mathrm{~mm}$, and $2.1-$ $2.5 \mathrm{~mm}$ ). Besides, it differs from both in the number of radial ribs in the umbilicus being approx. equal to that number on the outer surface of the last whorl, and in the radial sculpture which is often less distinct on part of the spire. 
Description. Shell small, thin, opaque to slightly translucent, white. Surface shiny. Spire ellipsoid (-obovoid), with three varices, apex slightly oblique or not. Whorls moderately convex, last whorl slightly convex, suture impressed; last whorl with an obtuse basal ridge which is bordered by a deep furrow on the umbilical side, umbilical side with a distinct, obliquely transverse bulge near the aperture, umbilical surface otherwise convex, with one distinct, rounded spiral ridge; last 1/4 whorl detached, rather close to the spire. Sculpture. Protoconch approx. smooth. Teleoconch. Radial sculpture present on most of the spire except the apical whorls, most distinct on the last whorl (particularly towards the base) and towards the sutures of the other whorls: rather well-spaced, low, wide, flattened, only slightly curved riblets which start as a slight crenulation below the suture; umbilicus with rather distinct, rather closely spaced, flat radial ribs, approx. as many as on the outer surface of the last whorl. Spiral sculpture absent. Aperture approx. circular. Peristome thickened and widely spreading, receding on the upper palatal side. Four apertural teeth: one prominent angular lamella starting on the edge of the peristome, highest where it almost meets the front end of the palatalis, behind this point slightly depressed but still running parallel and close to the crest of the palatalis, then continuing deep inside; one palatalis which starts slightly behind the inner edge of the peristome as a knob with a shallowly incised crest to accommodate the crest of the angularis, then continues as a single-crested lamella which ends somewhat abruptly well before the end of the angular lamella; one palatobasal knob deep inside the aperture; one columellar lamella rather deep inside the aperture, well behind a slightly convex part close to the inner edge of the peristome.

Dimensions: shell height 7.2-8.1 mm; shell width 3.0-3.3 mm; spire height $5.0-5.8 \mathrm{~mm}$; spire width 3.0-3.2 mm; spire $\mathrm{h} / \mathrm{w}$ index $1.7-1.9$; number of whorls 7-7 5/8; umbilicus $0.25-0.40 \mathrm{~mm}$ wide, or $8-13 \%$ of spire width; aperture height and width 2.0-2.3 mm.

Ecology. Slightly disturbed primary forest on deeply dissected limestone plateau, partly covered with clastic sediment. Altitude 0-100 m a.s.l.

Distribution. Indonesia, Kalimantan Timur, Sangkulirang peninsula, c. $60 \mathrm{~km} \mathrm{S.E.} \mathrm{of} \mathrm{Berau.} \mathrm{So}$ far known from the type locality only.

Etymology. From 'auriculatus' (Latin), 'with an ear', referring to the aperture shape.

\section{Diaphera crassa sp. nov.}

Figs 11-13

LSID 0EE66997-0261-4EB3-B2BB-8A089F790D97

Examined material. Indonesia: Kalimantan Timur. Sangkulirang Peninsula: Gua Ampanas near
Kampong Pengadan (V11857/1 shell); Gua Mardua near Kampong Pengadan (V11859/>10); Tabalar R. c. $50 \mathrm{~km}$ S.E. of Berau (holotype: HNHM 104876, paratypes: V11858/>10).

Diagnosis. It particularly resembles $D$. sororcula, but differs in its larger size (compare spire width: 2.7$3.6 \mathrm{~mm}$, versus $2.1-2.5 \mathrm{~mm}$ ), and in the wider umbilicus $(0.8-1.3 \mathrm{~mm}$, or $25-38 \%$ of spire width versus $0.30-0.55 \mathrm{~mm}$, or $14-25 \%)$. It differs from $D$. auriculata in its wider umbilicus $(0.8-1.3 \mathrm{~mm}$, or $25-38 \%$ of spire width, versus $0.25-0.40 \mathrm{~mm}$, or $8-13 \%$ ).

Description. Shell small, thin, opaque to slightly translucent, white. Surface shiny. Spire ellipsoid to ellipsoid-(ob-)ovoid, with three varices, apex not oblique. Whorls: apical whorls moderately convex, other whorls slightly convex, suture impressed; last whorl obtusely angular at the base and with a deep furrow close to the base on the umbilical side, umbilical side with a distinct, obliquely transverse bulge near the aperture, umbilical surface otherwise convex, with one slight, rounded spiral ridge; last $1 / 4$ whorl detached, close to the spire. Sculpture. Protoconch approx. smooth. Teleoconch. Radial sculpture present and distinct on most of the spire except the apical whorls, most distinct on the last whorl, towards the base: (rather) well-spaced, low, narrow, only slightly curved but on the first part of the last whorl often more distinctly curved riblets; umbilicus with rather distinct, rather densely arranged, narrow radial riblets distinctly fewer in number than on the outer surface of the last whorl. Spiral sculpture absent. Aperture approx. circular to broadly obovate. Peristome thickened and spreading, receding on the upper palatal side. Four apertural teeth: one prominent angular lamella starting on the edge of the peristome, highest where it almost meets the front end of the palatalis, behind this point slightly depressed but still running parallel and close to the crest of the palatalis over a short distance, then continuing deep inside; one palatalis which starts slightly behind the inner edge of the peristome as a knob with an oblique or shallowly incised crest to accommodate the crest of the angularis, then continues as a short, single-crested lamella; one palatobasal knob deep inside the aperture; one columellar lamella deep inside the aperture.

Dimensions: shell height $5.2-8.0 \mathrm{~mm}$; shell width 2.8-3.6 mm; spire height $3.5-5.9 \mathrm{~mm}$; spire width 2.7-3.6 mm; spire $\mathrm{h} / \mathrm{w}$ index $1.2-1.8$; number of whorls $53 / 4-83 / 8$; umbilicus $0.8-1.3 \mathrm{~mm}$ wide, or $25-38 \%$ of spire width; aperture height $1.6-2.2 \mathrm{~mm}$; aperture width $1.6-2.1 \mathrm{~mm}$.

Ecology. Disturbed lowland rainforest on limestone bedrock, also found persisting in about 10-year-old regrowth of Piper and Lantana after fire. Altitude 0-300 m a.s.1. 
Distribution. Indonesia, Kalimantan Timur, Sangkulirang peninsula.

Etymology. From 'crassus' (Latin), 'thick', referring to the short and wide spire.

\section{Diaphera sororcula sp. nov.}

Figs 14-15

\section{LSID 1921C654-76E6-47CA-8E21-C87C909FEF97}

Examined material. Indonesia: Kalimantan Timur. Sangkulirang Peninsula: Gua Ampanas near Kampong Pengadan (holotype: HNHM 104881, paratypes: V11853/>10 shells); Gua Mardua near Kampong Pengadan (V18381/1).

Diagnosis. It particularly resembles $D$. crassa, but differs in its smaller size (compare spire width: 2.1$2.5 \mathrm{~mm}$, versus $2.7-3.6 \mathrm{~mm}$ ), and in the narrower umbilicus $(0.30-0.55 \mathrm{~mm}$, or $14-25 \%$ of spire width, versus $0.8-1.3 \mathrm{~mm}$, or $25-38 \%)$. It differs from $D$. auriculata in its smaller size (shell height 4.9-5.9 mm, width $2.1-2.5 \mathrm{~mm}$, versus $7.2-8.1 \mathrm{~mm}$, and $3.0-$ $3.3 \mathrm{~mm}$ ).

Description. Shell small, thin, opaque to slightly translucent, white. Surface shiny. Spire ellipsoid to ovoid, with 3-4 varices, apex not oblique. Whorls: first whorls moderately convex, grading to an almost flat to slightly convex last whorl, suture impressed; last whorl obtusely angular at base, on the umbilical side with a furrow close to the base, with a rather distinct, obliquely transverse bulge near the aperture, umbilical surface otherwise convex, with one slight, rounded spiral ridge; last 1/4 whorl detached, close to or somewhat distant to the spire. Sculpture. Protoconch approx. smooth. Teleoconch. Radial sculpture present and distinct on most of the spire except the apical whorls, in some shells most distinct on the last whorl, towards the base: moderately spaced to densely arranged, low, narrow, not or hardly curved riblets, except on the first part of the last whorl in some shells where they are more distinctly curved; umbilicus with rather distinct, rather closely spaced, narrow radial riblets distinctly fewer in number than on the outer surface of the last whorl. Spiral sculpture absent. Aperture approx. circular to broadly elliptic to broadly obovate. Peristome thickened and spreading, receding on the upper palatal side. Four apertural teeth: one prominent angular lamella starting on the edge of the peristome, highest where it almost meets the front end of the palatalis, behind this point slightly depressed, in some shells running parallel and close to the crest of the palatalis, then continuing deep inside; one rounded palatal knob which starts slightly behind the inner edge of the peristome, and which may have a short, thin, lamella-shaped extension inside the aperture; in some shells this extension is almost separated from the palatal knob; one palatobasal knob rath- er deep inside the aperture; one columellar lamella deep inside the aperture.

Dimensions: shell height 4.9-5.9 mm; shell width $2.1-2.5 \mathrm{~mm}$; spire height $3.2-4.1 \mathrm{~mm}$; spire width $2.1-2.5 \mathrm{~mm}$; spire $\mathrm{h} / \mathrm{w}$ index $1.4-1.8$; number of whorls 5 3/4-6 7/8; umbilicus $0.30-0.55 \mathrm{~mm}$ wide, or $14-25 \%$ of spire width; aperture height 1.2 $1.5 \mathrm{~mm}$; aperture width $1.3-1.6 \mathrm{~mm}$.

Ecology. Found in about 10-year-old regrowth of Piper and Lantana after fire. Altitude 0-100 m a.s.l.

Distribution. Indonesia, Kalimantan Timur, Sangkulirang peninsula.

Etymology. From 'sororcula' (Latin), diminutive of 'soror', 'sister', referring to its comparatively small size.

\section{Diaphera rhysauchen sp. nov.}

Diagnosis. Identified within its group three by the presence of two or more spiral ridges on the umbilical surface of the last whorl: the upper the most distinct towards the aperture, elsewhere subordinate to or almost absent behind a distinct ridge immediately below it which, towards the aperture, gradually decreases to an inconspicuous, low and flat ridge or almost entirely disappears. Besides, it differs in the more distinct basal ridge on the last whorl, which is well-demarcated on both sides. Furthermore, it shares the locally inconspicuous radial sculpture with $D$. auriculata but differs in the wider umbilicus (0.7-0.9 mm wide, or $22-30 \%$ of spire width, versus $0.25-0.40 \mathrm{~mm}$, or $8-13 \%)$.

Description. Shell small, thin, opaque to slightly translucent, white. Surface shiny. Spire (ovoid-)ellipsoid to obovoid (rarely cylindrical), with $2-3$ varices, apex straight or hardly oblique. Whorls moderately convex, last whorl slightly to moderately convex, suture impressed; last whorl with an obtuse basal ridge well-demarcated on both sides, on the umbilical side with a rather distinct, obliquely transverse bulge near the aperture and with 2-4 spiral ridges: the upper the most distinct towards the aperture, elsewhere subordinate to or almost absent behind a distinct ridge immediately below it which, towards the aperture, gradually decreases to an inconspicuous, low and flat ridge or almost entirely disappears, below this near the aperture with or without two low, flat and even less conspicuous ridges; last $1 / 4$ whorl detached, usually rather distant from the spire. Sculpture. Protoconch approx. smooth. Teleoconch. Radial sculpture present on most of the spire except the apical whorls, on all whorls equally distinct or most distinct on the last whorl (particularly towards the base) and only locally present on the other whorls: (rather) well-spaced, low, narrow, only slightly curved riblets, except on the first part of the last whorl where they are more distinctly curved, which all start as a slight crenulation below the suture; umbilicus with locally rather distinct, rather densely arranged, narrow ra- 
dial riblets distinctly fewer in number than on the outer surface of the last whorl. Spiral sculpture absent. Aperture approx. circular to broadly obovate. Peristome thickened and spreading, receding on the upper palatal side. Four apertural teeth: one prominent angular lamella starting on the edge of the peristome, highest where it almost meets the front end of the palatalis, behind this point slightly depressed but still running parallel and close to the crest of the palatalis, then continuing deep inside; one palatal lamella which starts on or slightly behind the inner edge of the peristome with an obliquely flattened crest or with a bifurcation to accommodate the crest of the angular lamella; one knob-shaped or shortly lamellate palatobasalis rather deep inside the aperture; one columellar lamella deep inside the aperture,
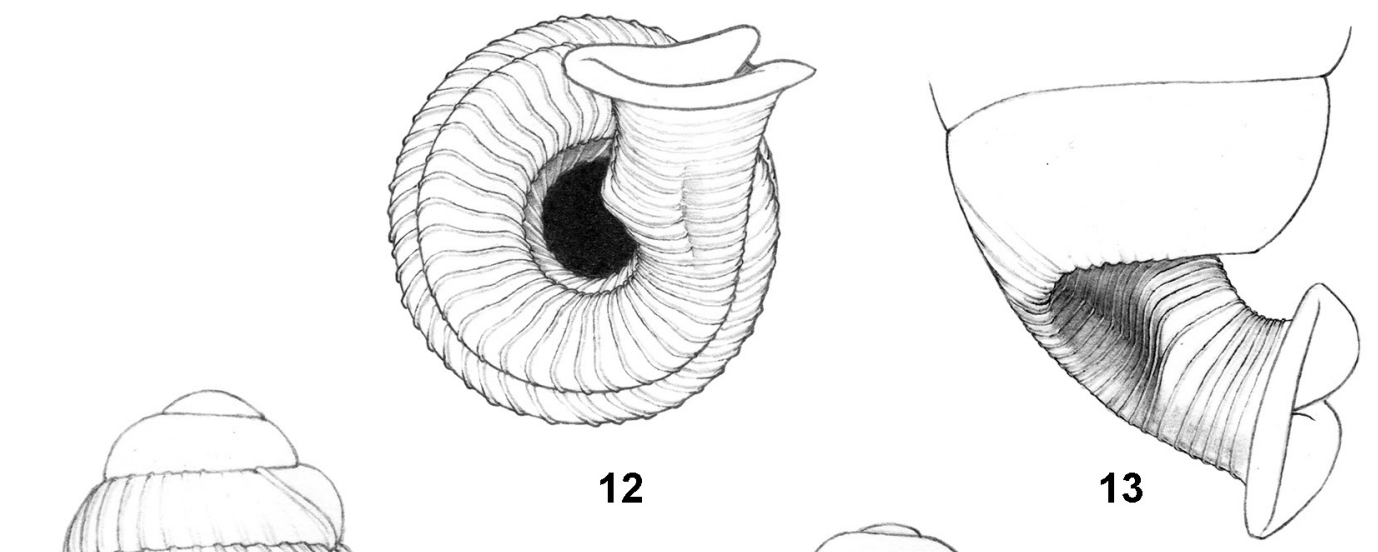

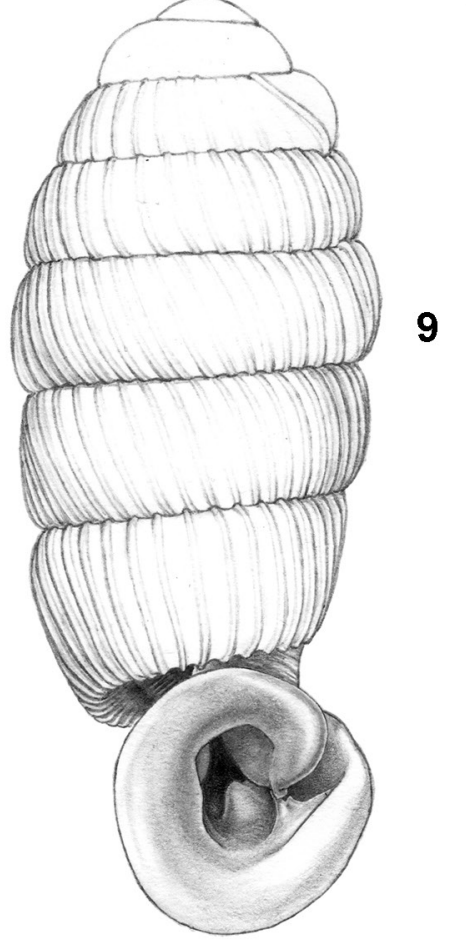

9

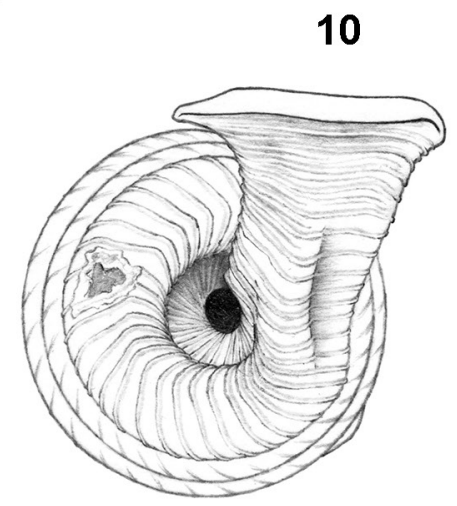

12

11

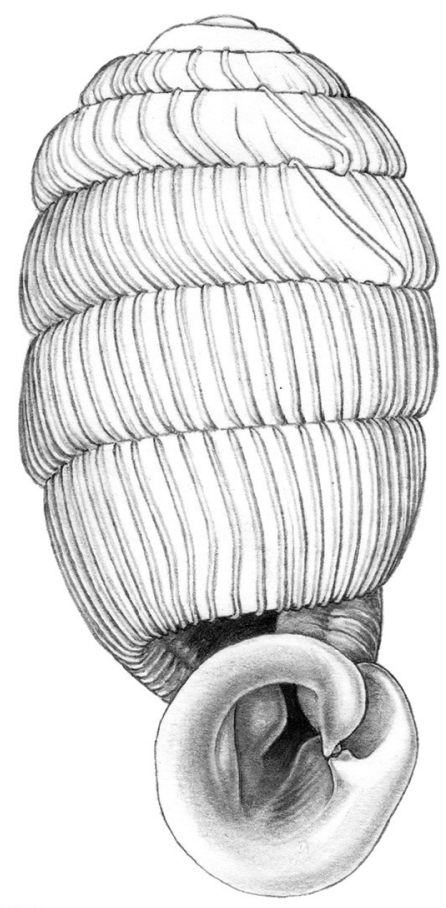

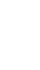

14

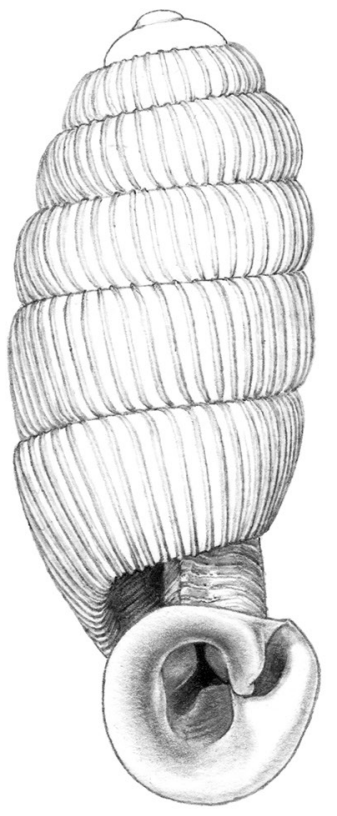

15

Figs 9-15. Diaphera Group 2: 9 - Diaphera auriculata sp. nov., holotype, frontal view, shell height 8.0 mm, 10 - same shell, umbilical view; 11 - Diaphera crassa sp. nov., holotype, frontal view, shell height $7.0 \mathrm{~mm}, 12$ - same shell, umbilical view, 13 - same shell, left lateral view; 14 - Diaphera sororcula sp. nov., holotype, frontal view, shell height $5.8 \mathrm{~mm}$, 15 - same shell, umbilical view 
well behind a slightly convex part of the shell wall close to the inner edge of the peristome.

Dimensions: shell height 6.2-8.4 (-10) mm; shell width 3.1-3.6 mm; spire height 4.0-5.4(-7.2) mm; spire width $3.0-3.3 \mathrm{~mm}$; spire $\mathrm{h} / \mathrm{w}$ index $1.2-1.7(-$ 2.4); number of whorls $53 / 4-71 / 8(-9)$; umbilicus $0.5-0.9 \mathrm{~mm}$ wide, or $15-30 \%$ of spire width; aperture height and width $1.8-2.2 \mathrm{~mm}$.

\section{Diaphera rhysauchen rhysauchen subsp. nov.}

Figs 16-18

\section{LSID D15304BF-EDD0-4A43-B1CB-A5647875C564}

Examined material. Indonesia: Kalimantan Timur. Sangkulirang Peninsula: Gua Ambulabung in the Baai River valley (holotype: HNHM 104879, paratypes: V11854/>10 shells); Tabalar R. c. 50 km S.E. of Berau (V18382/1).
Description. Body whorl on the umbilical side with two spiral ridges. Radial sculpture most distinct on the last whorl and only locally present on the other whorls. Dimensions. Umbilicus 0.7-0.9 mm wide, or 22-30\% of spire width.

Etymology. From 'ṕvбós' (Greek), 'wrinkle', and

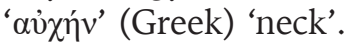

Ecology. Disturbed lowland rainforest on a slope with large limestone boulders, also found persisting in about 10-year-old regrowth of Piper and Lantana after fire. Altitude 0-300 m a.s.l.

Distribution. Indonesia, Kalimantan Timur, Sangkulirang peninsula.

Note. One shell in sample V 11854 differs in its longer, cylindrical shape with 9 whorls. It is included in the description above (measurements in brackets) but excluded from the paratype series.
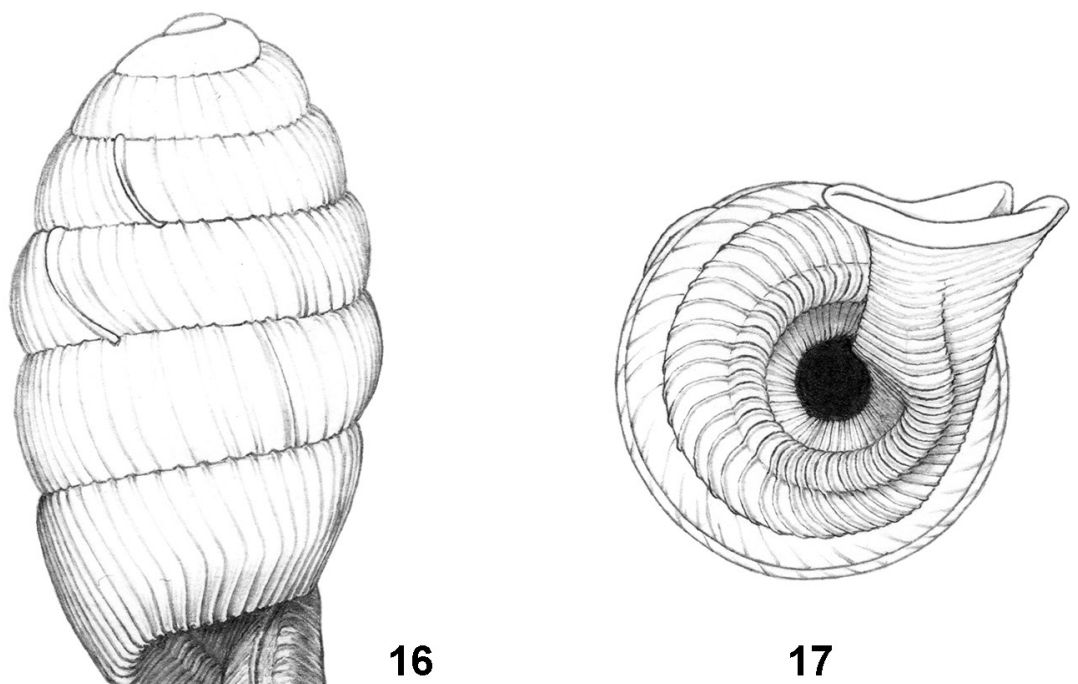

16
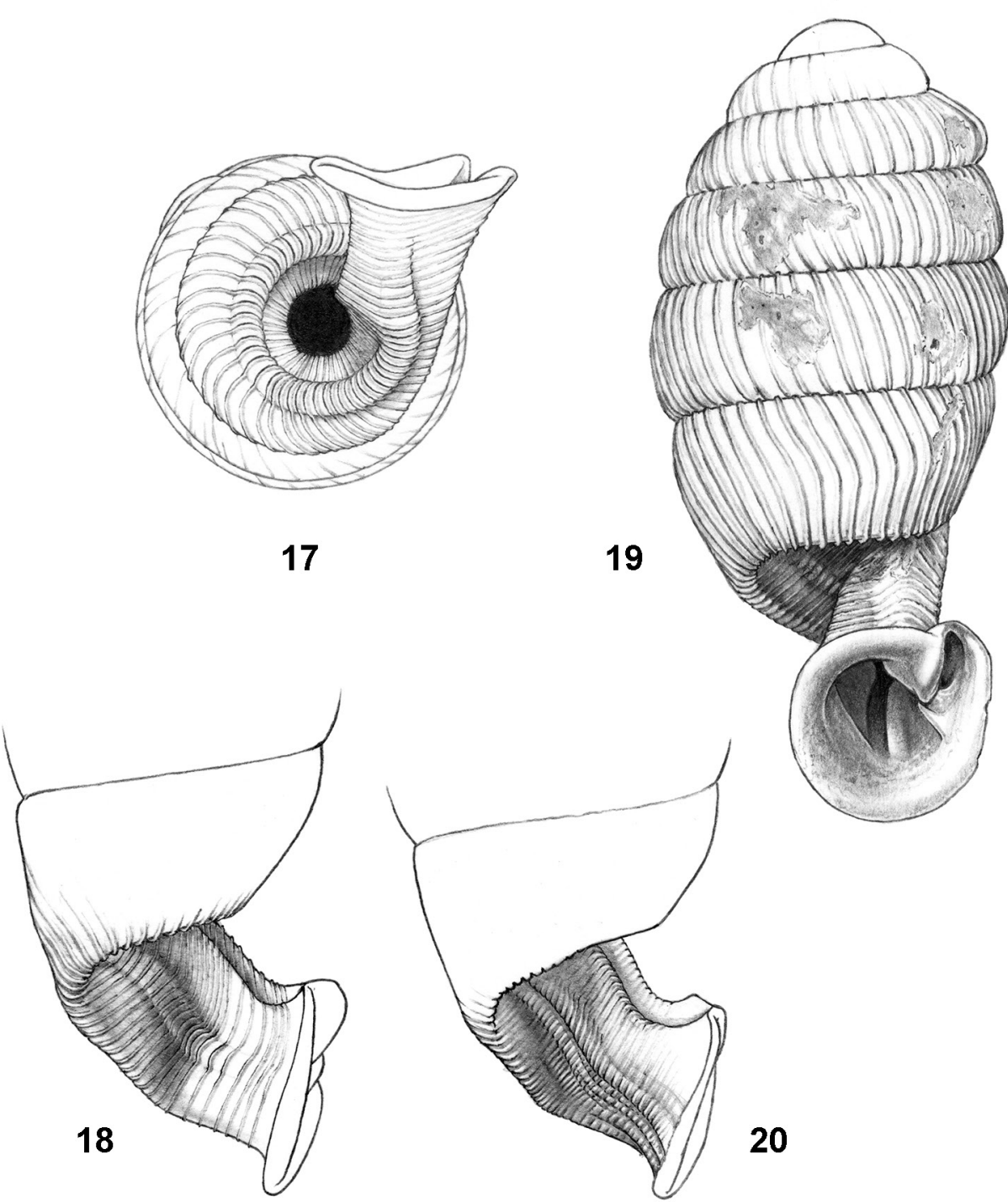

Figs 16-20. Diaphera Group 2: 16 - Diaphera rhysauchen rhysauchen subsp. nov., holotype, frontal view, shell height $8.2 \mathrm{~mm}$, 17 - same shell, umbilical view, 18 - same shell, left lateral view; 19 - Diaphera rhysauchen percostata subsp. nov., holotype, frontal view, shell height $7.4 \mathrm{~mm}, 20$ - same shell, left lateral view 


\section{Diaphera rhysauchen percostata subsp. nov.}

Figs 19-20

\section{LSID 0E66C3AD-7B9B-4CBA-ABEB-16FB9971E776}

Examined material. Indonesia: Kalimantan Timur. Sangkulirang Peninsula: Gua Mardua near Kampong Pengadan (holotype: HNHM 104880).

Description. Body whorl on the umbilical side with four spiral ridges: below the upper two, near the aperture two short, low, flat inconspicuous ridges. Radial sculpture present and distinct on most of the spire except the apical whorls. Dimensions. Umbilicus c. $0.5 \mathrm{~mm}$ wide, or c. $15 \%$ of spire width.

Etymology. From 'costatus' (L.), 'ribbed', the prefix 'per-' to indicate that the ribs are distinct over the entire spire.

Ecology. Found in about 10-year-old regrowth of Piper and Lantana after fire. Altitude $100 \mathrm{~m}$ a.s.l.

\section{REFERENCES}

Albers J. C. 1850. Die Heliceen nach natürlicher Verwandtschaft systematisch geordnet. Enslin, Berlin. https://doi.org/10.5962/bhl.title.11507

CHEN Z.-Y., PÁLL-GERGELY B. 2020. First record of Diaphera Albers, 1850 (Gastropoda: Eupulmonata: Diapheridae) from China. Journal of Conchology 43: 637-640.

DANCE S. P. 1970. Non-marine molluscs of Borneo. I. Streptaxacea: Streptaxidae. Journal of Conchology 27: 149-162.

DANCE S. P. 1972. Bruggennea, n. gen., proposed for recent streptaxids from Borneo (Gastropoda: Streptaxidae). Archiv für Molluskenkunde 102: 131-132.

GRAY J. E. 1860. On the arrangement of the land pulmoniferous Mollusca into families. The Annals and Magazine of Natural History, series 3, 6: 267-269. https://doi.org/10.1080/00222936008697321

HidALGO J. G. 1889. Espèces nouvelles ou peu connues de coquilles terrestres des îles Philippines. Journal de Conchyliologie 37: 296-306.

HUTTON T. 1834. On the land shells of India. Journal of the Asiatic Society of Bengal 3: 81-93.

Kobelt W. 1904. Die systematische Stellung der chinesischen Ennea. Nachrichtsblatt der Deutschen Malakozoologischen Gesellschaft 36: 26-30.

LAIDLAW F. F. 1950. Description of a new genus of land-mollusc, belonging to the family Streptaxidae, from the Bau District of Sarawak. Sarawak Museum Journal 5: 370-372.

MARTENS E. VON 1884. Landschnecken aus Sardinien und aus Südost-Borneo. Sitzungsberichte der Gesellschaft Naturforschender Freunde zu Berlin 1884: 195-199. https://doi.org/10.5962/bhl.part.28990

PÁll-Gergely B., HunYAdi A., GREGoJ., SAJANS., TRIPATHY B., CHEN Z.-Y. 2020. A review of the Diapheridae
Distribution. Indonesia, Kalimantan Timur, Sangkulirang peninsula. So far known from the type locality only.

Notes. 1. Only a single shell available which, while displaying the diagnostic characters of the species, differs from the nominate subspecies in the presence of radial ribs over the entire spire, and in the narrow umbilicus.

2. The two lowermost spiral ridges on the umbilical side of the last whorl, close to the aperture, are best observed with tangential light.

\section{GROUP 3}

This group includes D. helenae Vermeulen, 1990, D. wilfordi wilfordi (Dance, 1970), and D. wilfordi ectyphus Vermeulen, 1990.

(Gastropoda: Eupulmonata: Streptaxoidea), with special emphasis on India and Myanmar. Raffles Bulletin of Zoology 68: 682-718.

QUADRAS J. F., MÖLLENDORFF O. F. VON 1895. Diagnoses specierum novarum ex insulis Philippinis. Nachrichtsblatt der Deutschen Malakozoologischen Gesellschaft 27: 105-121.

Sutcharit C., NAGgs F., WADE C. M., Fontanilla I., PANHA S. 2010. The new family Diapheridae, a new species of Diaphera Albers from Thailand, and the position of the Diapheridae within a molecular phylogeny of the Streptaxoidea (Pulmonata: Stylommatophora). Zoological Journal of the Linnean Society 160: 1-16. https://doi.org/10.1111/j.1096-3642.2009.00598.x

VERMEULEN J. J. 1990. Notes on the nonmarine molluscs of the island of Borneo 1. The genus Diaphera (Streptaxidae). Basteria 54: 159-165.

VERMEULEN J. J. 1991. Notes on the nonmarine molluscs of the island of Borneo 3. The genus Platycochlium (Gastropoda Pulmonata: Streptaxidae). Basteria 55: 165-171.

VERMEULEN J. J. 2007. Notes on the nonmarine molluscs of the island of Borneo 10. The genera Sinoennea, Bruggennea, and Huttonella (Gastropoda Pulmonata: Streptaxidae). Basteria 71: 169-176.

ZILCH A. 1961. Die Typen und Typoide des Natur-Museums Senckenberg, 24: Mollusca, Streptaxidae. Archiv für Molluskenkunde 90: 79-120.

Received: April 28th, 2021

Revised: May 25th/June 14th, 2021

Accepted: June 23rd, 2021

Published on-line: August 4th, 2021 